\title{
Appraisal of the Residential Real Estate in Latvia: The Case of Riga and Daugavpils
}

\author{
Oksana Ruzha ${ }^{1}$, Tatjana Tambovceva ${ }^{2}$, Iluta Arbidane ${ }^{3},{ }^{2}$ Riga Technical University, ${ }^{1,3}$ Daugavpils University
}

\begin{abstract}
The real estate sector plays an important role for the real economy. Econometric modeling is successfully applied to mass appraisal of real estate, which is one of the most classical economic tasks. The paper shows the results of the use of three models for the appraisal of the commercial value of residential real estate in Latvia. The authors have chosen two biggest cities in Latvia, i.e., the capital of Latvia - Riga and the regional center Daugavpils. The statistical analysis of the sales data for 2011-2012 has allowed distinguishing pricing factors of the residential real estate both at the regional level and at the level of a building and object of real estate. Modeling was conducted with the use of correlation and regression and cluster analyses. The additive and multiplicative models based on the regression equation and the model of the cluster analysis based on the method of parallel sectioning have been presented.
\end{abstract}

Keywords - Econometric models, solution trees, two-phase cluster.

\section{INTRODUCTION}

The real estate sector plays an important role for the real economy. But very often it is quite difficult to find official data on commercial property markets. Property valuation may be considered the heart of all real estate activity.

To appraise means the act or process of developing an opinion of value; an opinion of value. Mass appraisal is a systematized method of receiving estimation of market cost indices for the big group of homogeneous real estate objects applying methods of statistical processing of information on the basis of comparative analysis of a considerable number of analogues with the use of objectively measured pricing factors, which are common for all analogues.

Real estate as a tangible thing can be measured. Property rights in real estate are normally appraised at a Market Value. There are many definitions of Market Value, but a good working definition is the most probable price the property would bring if freely offered on the open market with both a willing buyer and a willing seller. The aim of the research is to investigate market of residential real estate of two cities (i.e., the capital of Latvia - Riga and the regional center Daugavpils) using a comparative approach of different econometric models.

For the estimation of the commercial value of residential real estate, the authors decided to use a comparative approach of different econometric models: correlation and regression analysis and solution trees. The comparative approach in estimation practice gives the most objective volume of the commercial value of the objects sold.

The correlation and regression analysis and methods of discrete space-parametric analysis have been used for the construction of econometric models. A two-phase cluster analysis and solution trees have been used for the classification of the objects.

For the preparation of the article and data analysis, the authors have used the official data of the State Land Service and the real estate company "Arco Real Estate" and for the statistic processing and analysis - application package IBM SPSS Statistics 19.

\section{THE METHOdOLOGY AND ModeL}

The most well-known modern statistical methods of real estate market research are correlation and regression analysis methods and a sectioning method as an option of cluster analysis.

The basic applied task of the correlation analysis is quantitative determination of closeness between a dependent feature on the one hand and a set of factorial features on the other. The closeness of linear connection is quantitatively expressed by a correlation coefficient. The task of regression analysis is to determine the direction and connection form between the dependent and factorial features (Benjamin, Guttery, \& Sirmans, 2004; Berrens \& McKee, 2004; Brown \& Harvey, 1982; Dizikes, 2010; Francke, Vos \& Janssen, 2008; Hietanen, 2004).

Thus, correlation and regression analyses can be specified as a set of mathematical procedures intended for measurement of closeness, direction and analytical expression of the form of connection. The data-out of such an analysis should qualitatively (structurally) and quantitatively specify the statistical model:

$$
V=f\left(x_{1}, \ldots, x_{k}\right),
$$

where $k$ - a number of factors; $V$ - an expectation value of a dependent feature at the given values of factors of cost $x_{1}, \ldots, x_{k}$.

It is possible to distinguish two principal models; each has its own specificity.

The additive model is as follows:

$$
V=C+B_{1} x_{1}+\ldots+B_{k} x_{k}
$$

where $x_{1}, \ldots, x_{k}$ - characteristics of a real estate object, $B_{i}-$ numerical coefficients at variable characteristics of the object, showing the contribution of corresponding characteristics to the cost.

The multiplicative model is as follows:

$$
V=B_{0} x_{1}^{B 1} \cdot \ldots \cdot x_{k}^{B k}
$$


The simple multiplicative model is reduced to an additive type through finding the logarithm.

According to the methodology of cluster analysis (Pace, 1995) the mass appraisal is created by sectioning of the set of data about the real estate objects' prices, and calculation of the model coefficients by comparing average values of the initial and truncated sets.

\section{A. Two-phase Cluster Analysis}

Cluster data must have quantitative and qualitative (categorical) variables with the sufficiently large volume of the data. For work with different types of data, the method of twophase cluster analysis is used. Zavadskas et al. (2004) used for the commercial property evaluation economic and social indices. The authors of the paper used for the evaluation the following quantitative and categorical variables:

- Quantitative variables are: object total space and value of the deal,

- categorical variables are: district, type of the building, and technical condition.

The cluster analysis helps to segment various groups of objects of residential real estate, being based on price-making factors.

\section{B. Solution Trees}

Methods of solution trees are intended for forecasting the belonging of objects of real estate to a particular class of values of dependent categorical variable (value of the deal) on the basis of values of predictor variables: district, type of the building, technical conditions and number of rooms. The algorithm of solution trees' construction allows us to solve classification tasks, and thus it facilitates interpretation of the results produced by the constructed model. The operation of the algorithms of construction of solution trees is based on the application of methods of the regression and correlation analyses. One of the most popular algorithms of this family is CART (Classification and Regression Trees) based on dividing the data in a tree branch into two affiliated branches; the further division of this or that branch depends on the amount of the initial data described by a particular branch. Other similar algorithms, for example, CRT (Current Reality Tree), allow dividing a branch into a bigger number of affiliated branches. In this case, the division is produced on the basis of the higher coefficient (of the data described by the branch) of correlation between the parameter, according to which there is a division and the parameter that should be predicted further (Pjateckij-Shapiro, 2009; Chubukova, 2012; Tindova, 2007; Din, Hoesli \& Bender, 2000).

\section{FINDINGS}

\section{A. The Additive Model of the Regression Model of the Estimation of Real Estate in Daugavpils and Riga}

For the calculation of the commercial value of an apartment, the authors used the equation of plural linear regression. Here, Sum of the deal acts as a dependent variable and the factors and it is able to influence the apartment cost as independent variables.

For the exception of independent variables the authors applied the Stepwize method. This method initially includes all independent variables into the equation of regression, and then serially deletes all variables whose correlation with criterion has a significance value above the set threshold value (Ruzha, Voronov \& Tambovceva, 2013). If the influence of any of the included variables becomes too weak, it is excluded from the equation.

Equation (4) has been received as a result:

$$
\text { Value of the deal }(f 1)=\text { Area } B+B 1+B 2+B 3+C
$$

If Residential district is Center, the model return $z 1=1$ and if the apartment is located in another city district, then $z 1=0$. If technical condition is perfect or good, then $z 2=1$. If type of the building is Prewar and Stalinist, then $z 3=1$. If type of the building is not equal to Prewar and Stalinist, then $z 3=0$.

To solve the problem of influence of this or that factor on a dependent variable, the authors used the standardized coefficients of linear regression $(\beta)$. The more the given independent variable correlates with other independent variables, the less absolute value of its coefficient $\beta$ is.

\section{TABLE I}

STANDARDIZED COEFFICIENTS OF REGRESSION (USING EQUATION (4))

\begin{tabular}{|l|c|c|}
\hline Standardized Coefficients & Daugavpils & Riga \\
\hline B & 0.659 & 0.604 \\
\hline$\beta 1$ (Residential district = Center) & 0.325 & 0.219 \\
\hline$\beta 2$ (Technical condition = perfect) & 0.137 & 0.230 \\
$\beta 2$ (Technical condition = good) & 0.094 & 0.138 \\
\hline$\beta 3$ (Type of the building = Prewar and Stalinist) & 0.114 & 0.215 \\
\hline R - the coefficient of multiple correlation & 0.879 & 0.834 \\
R2 - a determination coefficient & 0.773 & 0.695 \\
\hline
\end{tabular}

Analyzing data from Table I, it is possible to conclude that in Riga the strongest factors influencing the cost of apartments are type of the building and technical condition, but in Daugavpils - district. Sum of the deal is determined by cumulative influence of variables Micro-district, Type of the building, Technical condition and Total area of rooms.

\section{B. Multidimensional Multiplicative Regression Model Based on the Cadastral Value}

Usually all apartments in Latvian cities have different cadastral and commercial values. Sometimes the commercial value is $2-4$ times higher than the cadastral one. The same situation can also be observed in Riga and Daugavpils.

One of the highest impacts on the apartment value is exerted by the project type of the building. Apartments of Prewar and Stalinist type buildings have the highest commercial value (in Riga - 4.67 times higher, in 2.8 times higher), but the Lithuanian type and 103rd-series design have the highest cadastral value. 


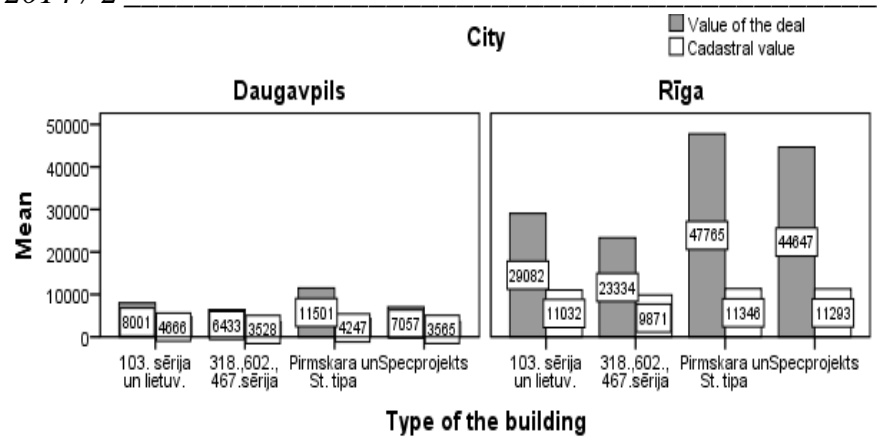

Fig. 1. Comparison of the average commercial and cadastral value of apartments of various types in Riga and Daugavpils.

There is also the effect of mutual influence of the Number of rooms and Project Type of the building on the correlation between the commercial and cadastral values of apartments. The biggest difference both in Riga and Daugavpils is observed for three-room apartments of Prewar and Stalinist type.
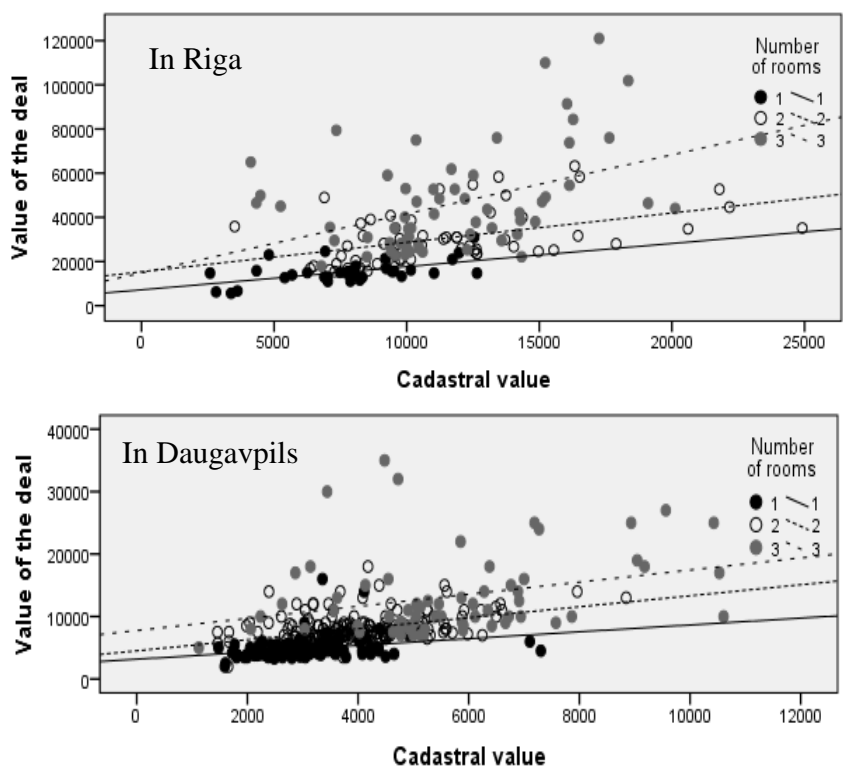

Fig. 2. Correlation of the commercial and cadastral values of the apartments with different number of rooms in Riga and Daugavpils.

The results of the analysis show that there is a close to the linear direct moderate significant correlation observed between Cadastral Value and the Sum of the Deal (in Daugavpils (Pearson Correlation, $r=0.569$ ); in Riga (Pearson Correlation, $r=0.495)$.

The analysis of the results shows that the application of econometric models is possible and has quite precise results and can be used for the estimation of the commercial value of the residential real estate in the Latvian real estate market.

\section{Classification of Apartments in Riga and Daugavpils Based on Their Price and Price-making Characteristics}

Two-phase cluster analysis in space of such price-making features as Amount of the deal, Micro-district, Type of the building, Technical condition, Number of rooms, Total area of rooms has allowed us to divide the real estate market of Riga and Daugavpils into homogeneous clusters.

There are four different clusters found by the authors in the market of real estate in Riga. The first one (39\%) is the cluster for two-room and three-room apartments in good condition, located outside the city center. These apartments are with the average apartment area of $57 \mathrm{~m}^{2}$ and the average cost 39145 EUR. The second cluster (18\%) contains one-room apartments in good technical condition and located outside the city center. These cluster apartments are with the average area of $36 \mathrm{~m}^{2}$ and with the average cost -22040 EUR.

The third cluster $(53 \%)$ is for the most expensive apartments (the average cost is 85420 EUR), these are threeroom apartments with the excellent technical condition. More than half of them are located in the city center, and they are Prewar and Stalinist type buildings.

The fourth cluster $(23 \%)$ is one- and two-room apartments located in the city center. The average area of such apartments is $49 \mathrm{~m}^{2}$ and with the average cost of 48083 EUR. Approximately $70 \%$ of such apartments are located in the city center and $57 \%$ are Prewar and Stalinist type buildings.

Daugavpils apartments' prices vary in a range from 4980 EUR to 25611 EUR and therefore the average cost is 11259 EUR. The Sum of the deal for a half of this group apartments ranges from 10671 EUR to 12379 EUR. Most of them $(72 \%)$ are two-room apartments with the average area of $50 \mathrm{~m}^{2}$. These apartments are not apartments of Prewar or Stalinist type and they are not located in the city center. The one third $(30 \%)$ of apartments in Daugavpils are cheap. The Sum of the deal for them is from 2845 EUR to 12805 EUR (the average Sum of the deal was 6536 EUR). Mostly they are one-room apartments with the average area of $31.5 \mathrm{~m}^{2}$ and in satisfactory condition; but only $7 \%$ of these apartments are located in the center. There are about $26 \%$ of Daugavpils apartments with the average cost of 17124 EUR and mainly there are apartments of Prewar and Stalinist type buildings located in the city center.

The analysis of all clusters allows concluding that it is possible to classify the real estate objects using quantitative and qualitative (categorical) indicators.

\section{Solution Trees}

The algorithm of solution trees' construction allows us to solve classification tasks, which makes it easy to interpret the results provided by the constructed model. There have been solution trees constructed for the classification of the objects of real estate in Daugavpils and Riga; such characteristics of apartments as Micro-district, Type of the building, Technical condition have been used at the input, and Sum of the deal served as the output.

The analysis of the solution trees allows us to forecast the commercial value of an apartment on the basis of simple rules such as:

- average cost of one-room apartments in buildings of series 318, 602, 467 in Riga is 23076 EUR; 


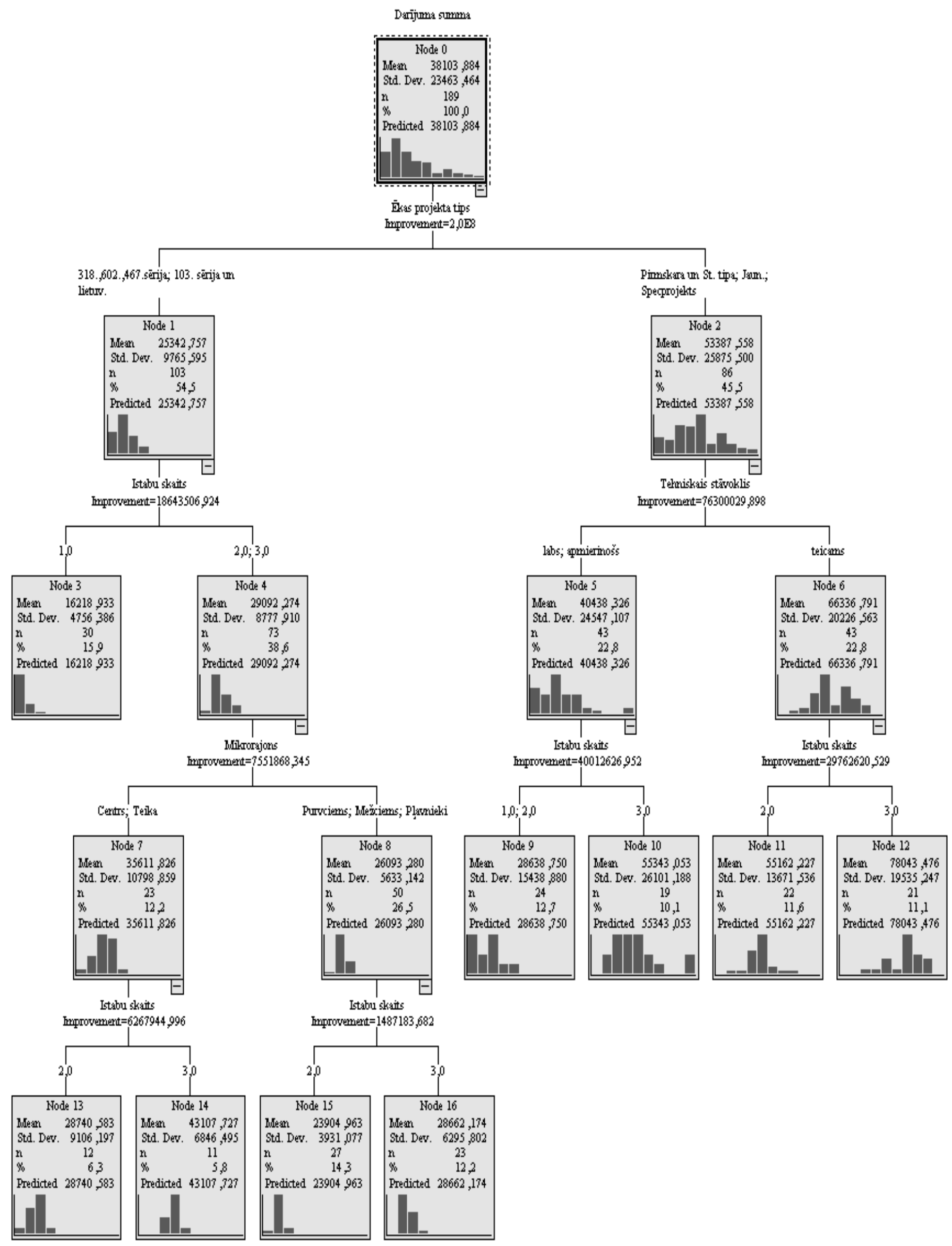

Fig. 3. Solution tree for classification of apartments in Riga. 
Baltic Journal of Real Estate Economics and

Construction Management

$2014 / 2$

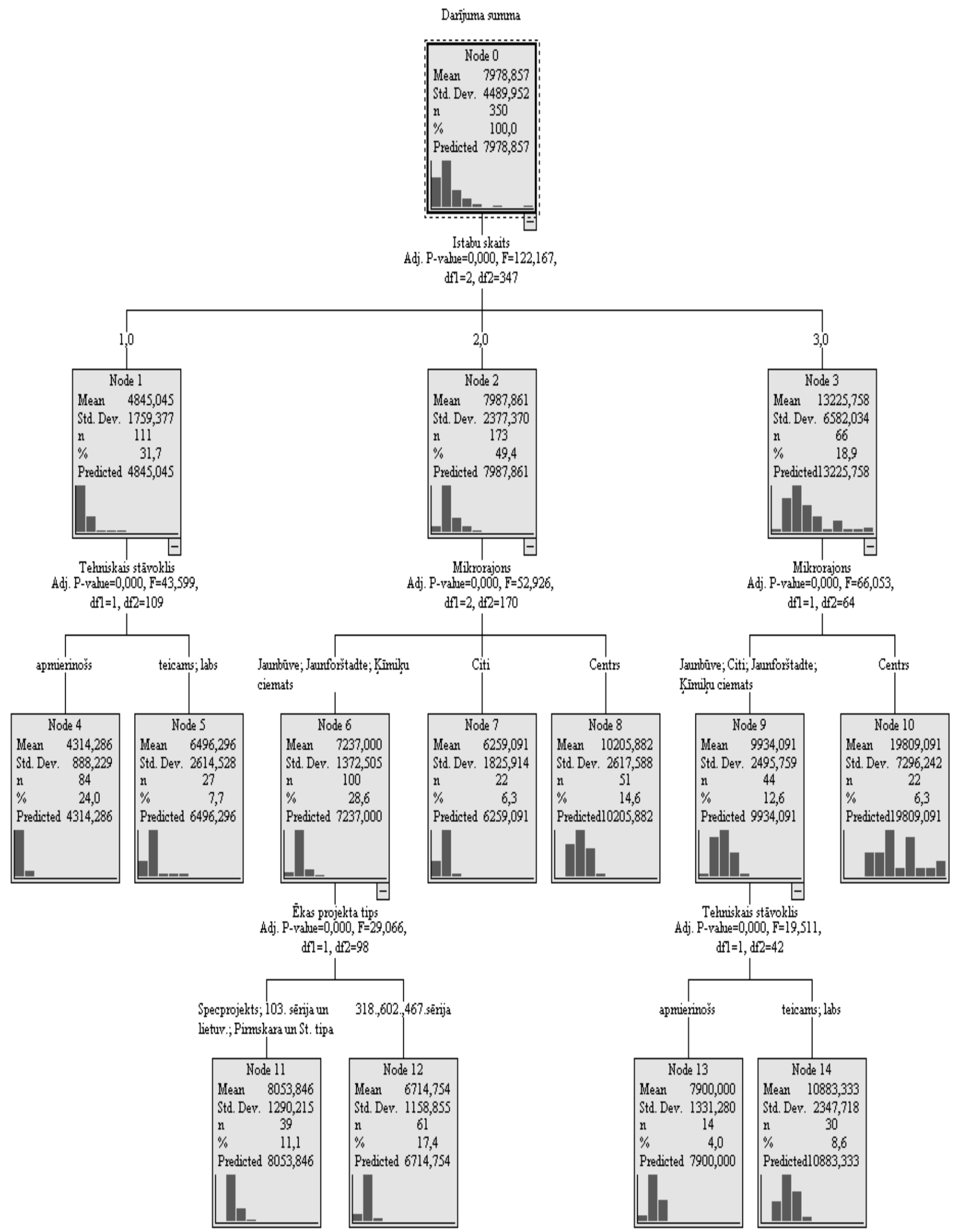

Fig. 4. Solution tree for classification of apartments in Daugavpils. 
- average cost of two-room apartments of Prewar and Stalinist type buildings in perfect technical condition in Riga is 21573 EUR;

- average cost of three-room apartments of Prewar and Stalinist type buildings in perfect technical condition in Riga is 111045 EUR;

- average cost of three-room apartments of Prewar and Stalinist type buildings in good or satisfactory technical condition in Riga is 78746 EUR;

- average cost of three-room apartments in buildings of series 318, 602, 467 and 103rd and Lithuanian design in Riga micro-districts of Purvciems, Mežciems, Pḷavnieki is 40782 EUR;

- average cost of two-room apartments in buildings of series 318, 602, 467 and 103rd and Lithuanian design in Riga micro-districts of Purvciems, Mežciems, Pḷavnieki is 34012 EUR;

- average cost of two-room apartments in buildings of series 318, 602, 467 and 103rd and Lithuanian design in Riga micro-districts of Teika and the center is 40893 EUR.

- average cost of three-room apartments in buildings of series 318, 602, 467 and 103rd and Lithuanian design in Riga micro-districts of Teika and the center is 61336 EUR;

- one-room apartment in Daugavpils in satisfactory technical condition would cost 6138 EUR on the average;

- one-room apartment in Daugavpils in perfect technical condition would cost 9243 EUR on the average;

- average commercial value of a two-room apartment in the center of Daugavpils is 14520 EUR;

- average commercial value of a three-room apartment in the center of Daugavpils is 28185 EUR;

- average commercial value of two-room apartments in Daugavpils located in Micro-districts of Jaunbūve, Jaunforštadte, Ķīmiķu ciemats in buildings of Prewar and Stalinist type and 103rd and Lithuanian design is 11458 EUR;

- average commercial value of two-room apartments in Daugavpils located in Micro-districts of Jaunbūve, Jaunforštadte, Kīmiḳu ciemats in buildings of series 318, 602, 467 is 9553 EUR.

The tree allows the authors to find out what percent of deals from the available set of data complies with the rule condition. In Daugavpils the greatest percent of deals (24\%) satisfy the rule: one-room apartment in Daugavpils in satisfactory technical condition will cost 6136 EUR on the average.

Besides, solution trees make it possible to analyze the discriminant capacity of price-making factors.

In the real estate market of Riga, the factor Type of the building has the greatest discriminant capacity. For apartments of Prewar and Stalinist type buildings the next significant factor is Technical condition, and for apartments of series 318 , 602, 467 and 103rd and Lithuanian design it is Number of rooms and Micro-district.

In Daugavpils the factor Number of rooms has the greatest discriminant capacity. The next significant factor for one-room apartments is their technical condition, for two-room and three-room apartments - Micro-district. Type of building is a significant factor for two-room apartments located in such micro-districts as Jaunbūve, Jaunforštadte, Ķ̄imiķu ciemats, for three-room apartments the technical condition is an important factor.

\section{CONCLUSION}

Commercial value of real estate objects always attracts the interest of people. The evaluation of the commercial value of real estate objects as a process includes investigating and analyzing the real estate market and the estimated object, creation of the model of this market in economical and mathematical terms, and finally, an estimation of the real estate objects from this market.

Both classifying (cluster analysis and solution trees) and forecasting (multidimensional regression models) econometric models are possible to use for the real estate object appraisal. But it is better to use combination of both models. But developing and application of this model is limited by the knowledge of mathematical statistics and computer software skills.

The performed analysis of the residential real estate estimate in Latvia has revealed that location and technical conditions of residential apartments are closely related to the market price of the residential apartments.

The research results and calculation of various models should improve forecasting of the commercial value of real estate objects.

For the future research the authors plan to analyze features of the Latvian market of the real estate in conditions of innovative progress of economy. The authors pay attention that in modern conditions it would be necessary to consider ecological components of operating projects. This direction slowly arises in Latvia and in the long term can capture all branches of economy both in industrial and in non-productive areas where it is necessary to apply new technologies and innovations. The generated ecological situation requires the use of innovative technologies in construction and reconstruction of the real estate.

Methods for real estate appraisal have been tested and improved for many years, ensuring high reliability in terms of the precision in determining market values.

\section{REFERENCES}

Benjamin, J., Guttery, R. \& Sirmans, R. (2004). Mass Appraisal: An Introduction to Multiple Regression Analysis for Real Estate Valuation. Journal of Real estate Practice and Education. 7 (1), pp. 65-77.

Berrens, R. \& McKee, M. (2004). What price nondisclosure? The effects of nondisclosure of real estate sales prices. Social Science Quarterly, 85, pp. 509-520. http://dx.doi.org/10.1111/j.0038-4941.2004.08502017.x

Brown, J. \& Harvey, R. (1982). On the Estimation of Structural Hedonic Price Models. Econometrica, pp. 765-768. http://dx.doi.org/10.2307/1912614

Dizikes, P. (2010). Explained Regression analysis. MIT News Ofiice. Retrieved from http://web.mit.edu/newsoffice/2010/explained_reg_analysis.html

Francke, M., Vos, G. \& Janssen, J. (2008). Standartised price indices for the regional housing market. Journal the Hierarchical Trend Model for Real Estate Valuation and Price Incices. p. 43.

Hietanen, J. (2004). Housing Market Analysis in Riga. Helsinki: Helsinki University, pp. 33-36. 
$2014 / 2$

Pace, K. (1995). Parametric, Semiparametric and Nonparametric Estimation of Characteristic Values Withing Mass Assessment and Hedonic Pricing Models. Journal Real Estate Finance and Economics, 11, pp. 195-217. http://dx.doi.org/10.1007/BF01099108

Pjateckij-Shapiro, G. (2009). Data Mining и перегрузка информацией. Вступительная статья к книге: Анализ данных и процессов [Data Mining and information overload. In Barsegjan, A. A., Kuprijanov, M. S., Holod, I. I., Tess, M. D., Elizarov, S. I. Data and processes analysis.] $3^{\text {rd }}$ ed. SPb.: BHV-Peterburg

Chubukova, I. (2012). Data Mining. Retrieved from: http://lnfm1.sai.msu.ru/ $\sim$ rastor/Books/Chubukova-Data_Mining.pdf

Tindova, M. (2007). K voprosu ob intellektualnoj obrabotke informacii v oblasti ocenki nedvižimosti [About the intellectual processing of information in the field of real estate appraisal]. Prikladnaja informatika. Naučno-praktičeskij žurnal. 5 (11), 25.

Din, A., Hoesli, M. \& Bender, A. (2000). Environmental variables and real estate prices. Urban Studies, 38 (11), pp. 1989-2000.

http://dx.doi.org/10.1080/00420980120080899

Ruzha, O., Voronov, V. \& Tambovceva, T. (2013). Econometric models for the estimation of the commercial value of residential real iestate objects in Latvia. Proceedings of the 2013 International Conference on Economics and Business Administration (EBA 2013). Business and Economics Series 8. pp. 104-110.

Zavadskas, E. K., Ustinovichius, L. \& Stasiulionis, A. (2004). Multicriteria valuation of commercial construction projects for investments purposes. Journal of Civil Engineering and Management X (2), pp. 151-166. http://dx.doi.org/10.1080/13923730.2004.9636299

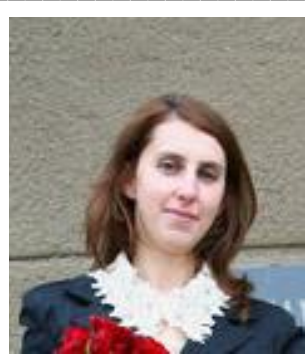

Oksana Ruža is the Researcher of Social Investigation, the Assistant Professor at the Faculty of Social Science. She has earned the Doctor's degree of Economics in Social Sciences at Daugavpils University. She is the author and co-author of more than 50 scientific publications. Her current research interests are focused on Sustainability Development Problems of Real Estate Market, on the Analysis of the Models of Mass Appraisal of Residential Real Estate. Her professional skills have been improved in Lithuania, Italy, Poland, Ukraine and elsewhere.

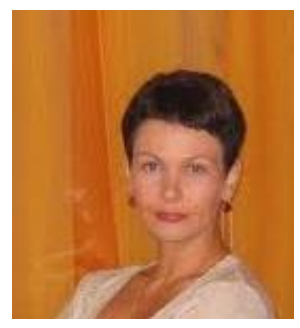

Tatjana Tambovceva is an Associate Professor at the Faculty of Engineering Economics and Management at Riga Technical University (Latvia), Doctor of Economics Sciences, Scientific Expert in Management Sciences of the Latvian Council of Science. She is a member of the International Society for Ecological Economics; member of the EURO Working Group OR in Sustainable Development and Civil Engineering (ORSDCE); member of Industrial Engineering and Operations Management (IEOM) Society "Achieving and Sustaining Operational Excellence"; senior member of the International Economics Development Research Centre (IEDRC); International Expert of Russian Humanitarian Science Foundation, etc. Tatjana specializes in: sustainable development, environmental management, environmental consumption and production, project management, management information systems, etc. She has more than 20 years of experience in business consulting; more than 80 publications, and she is a compiler or co-author of several books.

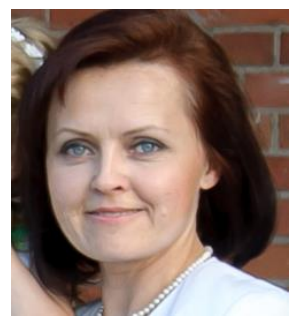

Iluta Arbidane is an Assistant Professor at the Faculty of Economics and Management, the Head of the Chair of Finance and Management of Rezekne Higher Education Institution (Rezeknes Augstskola (RA) in Latvia. She has earned the Doctor's degree of Economics (Finance) at Daugavpils University and Master's degree of Economics at Latvia University of Agriculture. Her professional skills have been improved in Lithuania, Austria, Germany, England and elsewhere. She is the author and co-author of more than 30 scientific publications. Her current research interests are focused on Sustainability Development Problems of Business, Business Finance Management. 